\title{
The Concept of Servant Leadership in Business Management
}

\author{
Dumisani Rumbidzai Muzira, $\mathrm{PhD}^{1} *$ \& Robert Muzira, D.Min ${ }^{2}$ \\ ${ }^{1}$ Marondera University of Agriculture Sciences and Technology, Zimbabwe \\ ${ }^{2}$ Solusi University, Zimbabwe
}

*Corresponding author: rdmuzira@muast.ac.zw

\begin{abstract}
This concept paper is a response to the calls for more research on servant leadership. It was propelled by the fact that many studies on leadership have focused on transformational leadership and team leadership in a midst of increasing interest on servant leadership. Although the servant leadership concept has been criticized for lack of empirical evidence, it is a viable option for this age which has been characterized by unethical dealings in the business world. In this situation, a leadership concept that appeals to human morals might therefore be the solution. The paper is based on literature search that seeks to explain the concept of servant leadership in business management by identifying its attributes, its antecedences and its outcomes. It also sought to make a distinction between leadership and management, authority and power in the context of servant leadership. A conceptual framework on servant leadership is then proposed. Practical examples on servant leadership as well as its criticisms are discussed. The conceptual framework will guide the organizations that seek to try out the servant leadership concept in their operations. It will also help individuals with the desire to become servant leaders on what is expected of them. Adoption of the servant leadership concept in organizations will also reduce the occurrences of business failures and financial scandals.
\end{abstract}

Key words: Servant leadership, management, authority, power

\section{Introduction}

Leadership is a subject that has been widely researched with many concepts on leadership being developed. These include transformational leadership, visionary leadership, team leadership and servant leadership. This paper is a concept paper on servant leadership that seeks to explain the concept by identifying its attributes, its antecedences and its outcomes. The study therefore focussed on the concept of servant leadership observing leadership from the angle of the behaviour that the leader portrays which is moral and ethical. More importantly, servant leadership depicts the leadership of Jesus Christ (Sendjaya, \& Sarros, 2002) which is an ideal model for present leaders. Although Christ was God, He became a servant to save His followers and be an example to them (Philippians 2:5-8). Servant leadership is however against the norm of other types of leadership where a leader possesses a lordship sense and a servant follows (Northhouse,
2013). The question that arises is how then can a leader be a servant?

The term servant leadership was coined by Greenleaf (1977) referring to a philosophy of serving others first and helping them to attain their potential objectives. Many models have been built of servant leadership such as the Russell and Stone (2002) model with twenty attributes and Patterson (2003) value-based model with seven constructs for servant leaders. The servant leadership concept's origin is from the story of a group of travellers with a servant among them who would constantly cheer them up as he served them in their journey. When the servant disappeared, the group could not continue with their journey as no one could cheer them up along the way. This then brought the travellers to the realisation that "the servant was actually their leader" (Greenleaf, 1977). Servant leadership is an approach to leadership which focuses on people, principles, and the "big picture. Servant leaders therefore serve

24 East African Journal of Education and Social Sciences (EAJESS) 1(1)24-32 
rather than impose, they empower rather than control. They see their work as a calling and not a career (Wis, 2002).

Since there is no one agreed definition of servant leadership, there is also no single way to measure it. Laub (1999), developed a conceptual model of six clusters of servant leadership characteristics (personal development, valuing people, building community, displaying authenticity, providing leadership and sharing leadership). Russell and Stone (2002) mentioned nine functional characteristics (vision, honesty, integrity, trust, service, modelling, pioneering, appreciation of others, empowerment) and eleven additional characteristics of servant leadership while the model of Patterson (2003) includes seven dimensions (love, humility, altruism, vision, trust, empowerment and service) p. 7. This paper therefore, aims at having the readers appreciate the concept of servant leadership since "no single measure can fully capture and operationalize complicated constructs-like servant leadership" (Van Dierendonck, \& Nuijten, 2011, p. 250).

With many studies done on leadership, organisations were not supposed to be experiencing any leadership problems. Organisations that fail due to lack of good leadership should have been extinct with such leadership theories as transformational leadership, authentic leadership, visionary leadership and team leadership. If leadership problems existed, solutions should have been discovered to wipe them out.

Despite all the studies done on leadership, organisations still fail due to bad leadership. The financial crises of 2008, the financial scandals such as the Enron scandal are partly a result of bad leadership. These leadership problems have a negative impact on the organisations, the employees, the customers and the community. Many companies were shut down due to the 2008 financial meltdown. Jobs were lost and families suffered as the bread winners became jobless. Customers lost their sources for supplies with the closure of some companies. Enron scandal also had US\$74 billion investor and employee funds lost including loss of jobs by employees. In some cases, top leaders such as the Chief Executive Officers (CEOs) and financial directors were fired or jailed negatively affecting the reputation and operations of their organisations. The financial crises and the scandals have ripple effects on the community thereby intensifying the problem Culpan, \& Trussel, 2005; Seeger, \& Ulmer, 2003).
Having realised that a leader influences his/her followers (Northhouse, 2013), it is important that the influence be in a positive direction. This study therefore, offers the servant leadership as one of the solutions to the leadership problems that the organisations are facing. Being the kind of leadership concept that has been practiced by Jesus Christ, servant leadership is likely to be the right solution. It is based on ethical behaviour and leading through serving which is lacking in most organisations. This study will be useful to organisations that may need to try-out servant leadership as well as individuals who desire to be servant leaders. The researchers therefore proposed a conceptual framework in Figure 1on servant leadership with its antecedents, attributes and outcomes.

\section{Authority and Power in Servant Leadership}

The way authority and power is expressed in servant leadership is different from the way it is understood using other leadership concepts. Servant leadership is in line with Mary Parker Follett's leadership concept that is based on the idea of integration and authority. Follett says, authority should be derived from one's influence on the subordinates not from one's position. She terms these scenarios "power with" and "power over" respectively (Wren, \& Bedeian, 2009). Unlike the power over condition, "power with" suggests that when a leader mingles with the subordinates, they influence them as they work together but when they are more like judges who rule over them, they can coerce them to work but not influence them. Rosenberg (2005) echoes the same when power is defined as the ability to force or coerce others to do your will, even if they would choose not to, because of your position or might. Authority, on the other hand, is the skill of getting others willingly to do your will because of your personal influence. Good influence can result in ripple effects of servant leadership while coercion does not bring about a lasting change of behaviour.

Wren and Barnard (2009) also support the same idea of shared power when he mentions that authority does not reside in persons of authority, but in a member's acceptance of authority This means that, even if a person holds a position of authority such as a manager, if the members do not accept his/her authority, that person has no authority because he/she has no influence on them. Barnard and Wren go on to define moral leadership, which is part of servant concept as having executives who have a high moral code, demonstrating it as an example and seeking to create this morality in others. This is in line with servant leadership where a leader should 
have good morals, lead by example and also influence followers to be servant leaders as well. A person of authority should therefore have an influence on the followers.

Sendjaya and Sarros (2002) have a similar view of servant leadership. To them, a servant leader should not have "power over" but "power to." This means that a servant leader has power to serve others not to be served. "Power over" implies force while "power to" implies persuasion and convincing. Unlike in other leadership type where power means control, in servant leadership, power is derived from the influence the leader has while serving the followers. The power is used to influence not to coerce or force.

\section{Servant Leadership versus Management}

Confusion often arises when one needs to distinguish servant leadership from management. Before moving to the concept of servant leadership, a few elements that can help in the distinction of these two terms are discussed. These include the primary intent, goal setting, relationships, operation and governance. Managers excel in stable environments by maintaining the status quo while leaders conquer the context of the volatile, turbulent and uncertain environment (Lunenburg, 2011). This therefore suggests that leaders are needed more than managers in order to survive the $21^{\text {st }}$ century's unstable environment.

The primary intent of a servant leader is to serve the interests of the followers while the primary intent of a manager, is to meet the organisation's objectives (Lunenburg, 2011). Obsession of outcomes and control by managers often brings fear of failure to subordinates hence jeopardizing progress. Therefore, to bring their best to work, people should feel motivated and purposeful (Cable, 2018). This does not mean that a servant leader is not concerned about the organisational objectives. It means that in the process of helping the followers attain their greatest potential, the organisational objectives will be met. A servant leader is there to serve others, while a manager exists to serve the organisation using the subordinates. A servant leader therefore values the people who form the organisation (Stone, Rusell, \& Patterson, 2004).

On goal setting, servant leaders articulates the vision, create the future and see the bigger picture (Lunenburg, 2011). Managers on the other hand execute plans, improve the present and have a narrow view. Servant leaders help their followers reach their potential thus focusing on the future while managers focus on what their subordinates can do best in the present. While servant leaders look at a bigger picture of the followers, the organisation and the environment, managers have a narrow view of just meeting organisational goals, thus executing what has been planned. This is one reason why most managers fail in turbulent environments.

Relationships are more important to the servant leader than results while a manager focuses more on the task results than relationships (Spears, 2010). Servant leaders treat their followers as colleagues and equals while managers treat them as subordinates who are inferior to them. Managers therefore, use their legitimate power to control their subordinates while servant leaders empower and influence their followers through their own service. While managers plan the work that the subordinates are to perform, servant leaders lead in performing the work together with the followers.

On operation, managers do things right while leaders do the right things. This then explains why servant leaders' behaviour is based on ethics and morals. Doing the right things calls for ethical behaviour while doing things right can go against ethics and morals. In their operation, servant leaders serve their subordinates while in management, subordinates serve their managers and the same managers in turn serve their superiors. In the area of governance, managers use authority while servant leaders use influence. In servant leadership, the leader leads by example while a manager controls and even uses force to have their way. The servant leader therefore, relies on self-sacrifice not self-glory while managers use their subordinates for their own recognition and promotion (Lunenburg, 2011).

\section{Methodology}

This work is a review done using the funnel literature review strategy. Literature search was done from broad to narrow (Joyner, Rouse, \& Glatthorn, 2013). Literature on leadership as a broad theme was done using Google scholar, the social sciences research network (SSRN), JSTOR, Wiley online libraries and some Management and leadership text books so as to have an overview of leadership concepts in business management. Accessed literature was then screened using the year of publication, relevance of the literature to the study and the credibility of the sources. Although preference was given to recent literature, old literature was also used for the background of the study and to support the study's theoretical 
underpinnings. The search then moved from broad and became more focused on servant leadership and even narrowed down to servant leadership in business management. In- depth reading on servant leadership was done in order to come up with the servant leadership conceptual framework as discussed in the sections below.

\section{Discussion}

This section discusses various concepts related to Servant Leadership by the use of related literature and studies.

\section{The Servant Leadership Attributes}

For Hunter (1989), "leadership is caught and not taught" (p. 77). This then puts a great responsibility on leaders to model what their followers should catch. For Hutcheson (1979), "leadership or management is an indispensable organizational function" (p. 163), and for any organization to grow and be effective, there has to be leaders that are positively informed. This therefore, requires a servant leader to have certain attributes such as good listening skills, good communicator and being compassionate, patient and honest (Hunter, 2004). A leader who naturally possess such attributes have greater chances of engaging in servant leadership. These mentioned attributes are a necessary vehicle that strengthens the way businesses are managed. Servant leadership therefore, has to do with behaviour and character. Unlike management which is about the things we do such as planning and organising, leadership is who we are. For Malphurs (1992), "a wise leader will recruit staff members who have strong gifts in areas where he is less gifted" ( $p$. 23). In this study, the servant leadership attributes are put into four categories which are; visionary, selfless, good communicator and stewardship. As follows:

\section{Visionary}

For George and Robert (1992), "leadership has three parts: setting of goals, obtaining goal ownership and equipping people for the work" (p. 16). Leadership as a process is the individual's ability to create a shared vision of the future. It is a fact that leaders without vision will perish and will not take people to any meaningful destination. Visionary leaders are those who can conceptualise ideas and have foresight. Conceptualising include dreaming big and having a vision. It has more to do with strategizing and directing the organisation. The leaders are the ones to dream while the managers are there to implement the dream. A servant leader should therefore be able to conceptualise and map the way the followers are to follow.
According to Malphurs (1992), when leaders are moulding goals into success, the following should be observed: "realizing the importance of a vision, defining the vision's key ingredients, developing a vision, communicating the vision, building a leadership team around the vision and preserving the vision in daily life"(p. 27). Visionary leaders know and see the future that their followers cannot see. They see the unseen potential in their followers and map ways to unleash that potential. This can be seen in the business world by examples such as KFC and Econet wireless Zimbabwe which started in their countries but expanded regionally and internationally as a result of visionary founders. These leaders can sense dangers before they are experienced and map ways in advance to circumvent those dangers. There is a thin line between foresight and intuition. While foresight involves calculated moves, intuition has more to do with feeling. A servant leader should therefore, have foresight which might be based from past experiences or observation of trends.

\section{Selflessness}

Selfless leaders being those that put followers' needs first, help followers grow and succeed and also empower the followers By putting others first, servant leaders put themselves in other people's shoes. This helps them understand their followers better even if they fail to behave according to their expectation. Empathy will also constrain the servant leader to be more empathetic too. Selfless people also help others grow and succeed. They are not jealousy, but rejoice even when others perform better than them. Their success is measured by how their followers perform in the way they execute their duties at work for the success of the entire enterprise. This then makes them empower their followers (Van Dierendonck, \& Nuijten, 2011). By empowering their followers, they are training them to be servant leaders as well. These leaders avail the resources needed for a specific task, train the followers how to use those resources efficiently and also observe the followers as they do the task. The followers are encouraged to do critical thinking hence innovation is high when followers are empowered. Empowerment, therefore acknowledges that other people have potential to lead as well.

\section{Good communicator}

Leaders who are good communicators are good listeners with ability to provide emotional healing to their followers and to persuade them. A servant leader should listen to what is being said and unsaid (Spears, 2010). Some followers might not say a word, but a good listener will hear what is unsaid as 
they seek to identify and clarify the will of their followers. Good communication needs patience and discernment on the part of the leader (Barter, 2019). Communication can be verbal or non-verbal but a good communicator would know where, when and which form of communication to use. It is paramount that leaders in the business world keep their employees informed of developments such as the financial position of the company, the budgetary constraints, business achievements and potential organizational threats for purposes of keeping afloat in business.

In a world full of pain, heart breaks and evil, healing of relationships is crucial. The sources of discouragement, pain and depression might be internal or external, personal or work related, all the same, the servant leader should be able to provide emotional healing for downcast followers. Emotional healing also incorporates forgiveness and acceptance. A servant leader should therefore give hope to the hopeless, be a good forgiver who also believes in the followers' potential against all odds. Good communicators do not force their way, they negotiate and persuade. Persuasion means somebody has been convinced and not coerced. Unlike the traditional authoritarian leadership, servant leadership does not force matters but it seeks for consensus with the followers. Persuasion therefore yields better results than coercion because a convinced follower tends to behave well even in the absence of the leader while the coerced one tends to pretend in the presence of the leader but behaves differently in their absence. Persuasion therefore results in more permanent behaviour changes that can form the servant's character (Jit, Sharma, Kawatra (2017).

\section{Stewardship}

A steward may be defined as somebody who has been entrusted with another person's property or assets. A servant leader should therefore be a steward who takes care of human beings, the most valuable asset of an organisation so that they attain their greatest potential. According to Van Dierendonck and Nuijten (2011), "stewardship is closely related to social responsibility, loyalty and team work" (p. 252). Stewardship encompasses management of resources as well. This entails taking care of the environment by reducing pollution and land degradation which have been caused in some cases by corporates in a bid to offload toxins. The servant leaders should therefore possess the stewardship attributes that include loyalty, ethical behaviour and social responsibility.
A steward is loyal to the owner of property or assets that they superintend, to the followers and to the organisation they work for. The leader's loyalty earns them respect from the people they serve. Their loyalty makes them accountable and dependable. A steward is expected to behave ethically. Likewise, a servant leader is expected to be ethical in their personal lives, professional life and all-round. Their lifestyle should be a good example to the followers. Therefore, stewardship entails a genuine concern over the welfare of others. This then results in servant leaders being socially responsible. Their selfless attribute contributes to them being concerned about the society. Their social responsibility should also involve caring for their environment (Dod, Achen \& Lumpkin ,2018).

\section{The Outcomes of Servant Leadership}

Servant leadership results in the improvement of follower performance and growth, organisational performance and societal impact.

\section{Follower Performance and Growth}

Servant leadership helps followers reach their potential in their different spheres of life, be it academically, socially, economically or otherwise. Servant leadership grooms subordinates to be servant leaders too. The servant leader has an influence on how the subordinates are to behave in the present and in the future. This idea is supported by Mary Parker Follett who says that leaders should not have power-over but power-with, coercion but co-action (Wren, \& Bedeian, 2009). This can be explained by the life of Jesus and how He influenced the disciples. Jesus modelled servant leadership and as a result James and John who were known as the sons of thunder (Mark 3:17) were changed to be fishers of men, patient and loving. Generally people learn from observation, so by observing their leader serving, the followers learn to serve others as well. Serving others would include helping co-workers and being good ambassadors of the organisation (Vondey, 2010). This would therefore result in the organisation having goodwill which is an asset to their business with high returns due to customer retention.

\section{Organisational Performance}

Servant leadership also promotes team spirit. If workers know that their leaders care for their needs, they get a sense of belongingness that promotes team spirit. The presence of the leader motivates them to work even more. It is incumbent upon leaders in the business world to take note of their employees' 
physical, mental, social and financial needs if their organization is to have improved performance. This is supported by one of the Hawthorne studies termed the relay assembly test room (1927-1933). Results on these studies showed that the leaders' presence, the support of employees and meeting the workers' social and physical needs had a positive influence on production (Wren, \& Bedeian, 2009). Servant leadership should promote organisational citizenship behaviour which enhances organisational performance.

\section{Societal Impact}

The society also benefits from servant leadership. The servant leader's concern about the wellbeing of the followers has an influence on the society and the environment. This then influences the corporate social responsibilities that organizations are involved in to assist the communities that corporates operate in. This is evidenced by the work of Mother Teresa, a Catholic Nun, whose life of service as a leader benefitted the society in general. The details of her contribution to society are discussed in this paper.

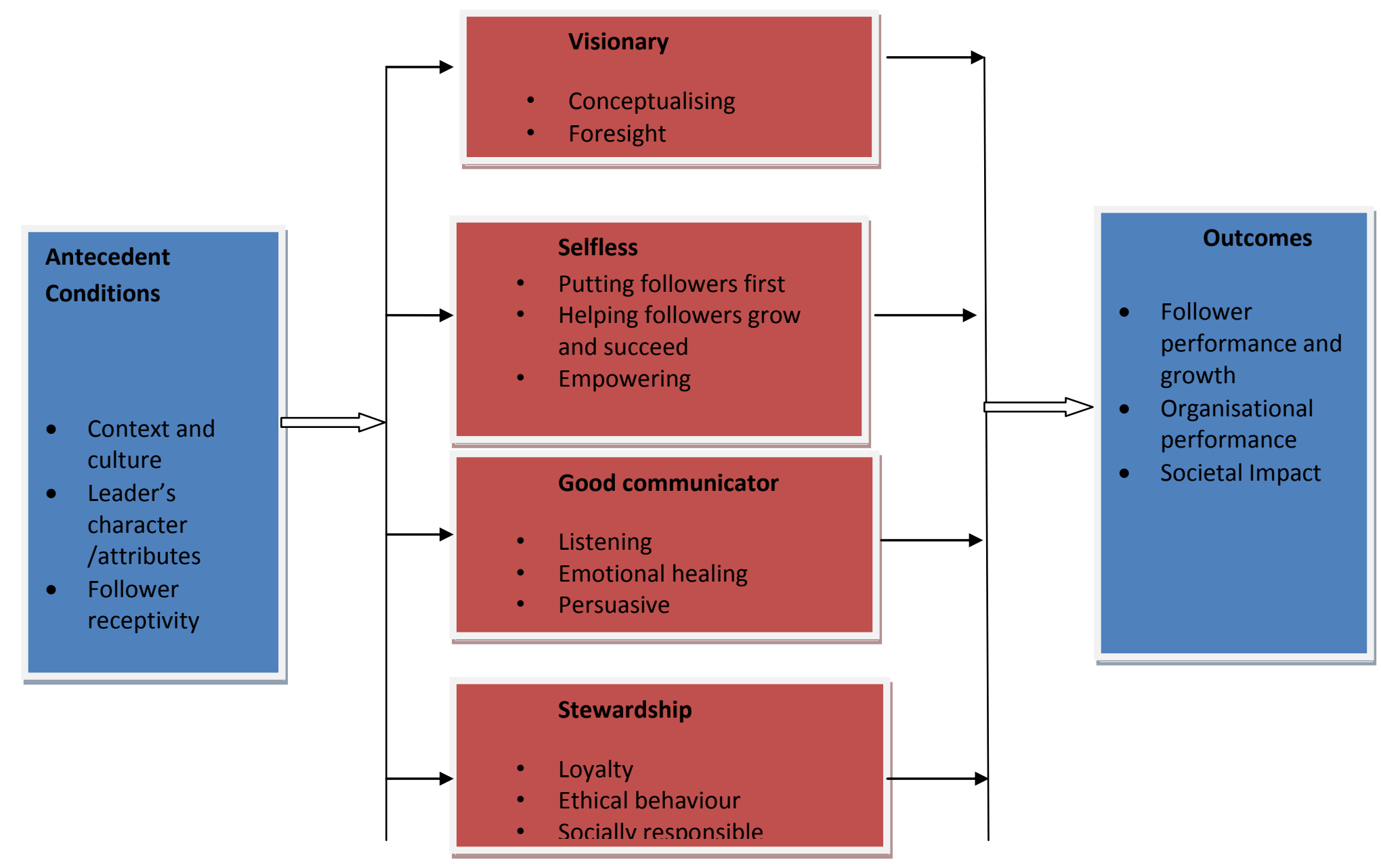

Figure 1: The Conceptual Framework for Servant Leadership

\section{Practical Examples of Servant Leadership}

Although there are few empirical studies that have been done on servant leadership, the concept has been in practice since The Bible times. The concept has been used in the community, in politics, in the business sector and in the Bible. Characters such as mother Theresa, Corazon C. Aquino, Moses and Jesus Christ reflect the practice of servant leadership. Businesses such as the Southwest airlines also benefited from the practice of servant leadership 
(Chawla, 2002; Udani, \& Lorenzo-Molo, 2012; Wilkes, 1998).

\section{In the Community/Society}

The life of mother Theresa is one practical example of servant leadership. She lived a selfless life dedicated to helping others. She started Missionaries of charity, home for the dying, hospice for leprosy disease, orphanage and homes for HIV and Aids patients. The missionaries of charity helped the hungry with food, clothed those who lacked clothes and gave home to the homeless. She cared for the societal outcasts not just financially but by serving them, being there and working for the needy (Chawla, 2002).

\section{In Politics}

The life of former Philippine president, Corazon C. Aquino is another example of servant leadership in practice. Udani and Lorenzo-Molo (2012) in their study of the life of Aquino observed that she had the attributes of a servant leader such as integrity, spirituality, exemplary character, humility and simplicity and people-centeredness. Her example shows that servant leadership cuts across disciplines and gender. She dedicated her life to serving the Philippines despite her husband's death and earned respect among many leaders in the Philippines to the extent of calling her influence "Cory Magic" (Udani, \& Lorenzo-Molo, 2012, p.389). Servant leadership can therefore be applicable not only in business, but in politics as well. The concept can be used by both males and females.

\section{In the Bible}

Moses is one Bible character that practiced servant leadership. He was willing to be spent while serving the Israelites (Exodus 18: 13-16). After the advice from Jethro, his father in law, Moses then empowered and delegated his followers to rule over Israel on small matters (Exodus 18: 25-26). He also showed the character of a servant leader when he pleaded with God to delete his name from the book of life and save the Israelites (Exodus 32:32). This gesture showed compassion and love for his followers which are some of the servant leadership attributes. This plea also reveals the selfless spirit in Moses by offering to lose heaven for the sake of his followers. Characteristics of a servant leader according to Isaiah 53 include: nonappearance (vv. 2,3), identification with people (vv. 4,5), healing (v. 5), responsibility for others (v. 6), non-violence, lack of oppression (v. 7), servant of God; chosen and called by God (vv. 1,10), inclusiveness (v. 11), working on behalf of people, with them as well as and not against them (v. 12). Traces of all these characteristics could be seen in the life of Moses.

The life of Jesus is also a perfect example of servant leadership in practice. Jesus as leader came to be equal with men in order to be an example to them. His servant leadership is revealed by His attitude and the influence he had on His followers. That same attitude is expected from those who are Christ's followers, "let this mind be in you which was in Christ Jesus...” (Philippians 2: 5); “...whoever desires to become great among you shall be your servant..." (Mark 10: 43-45). These verses reflect the concept of a leader that serves. Another incidence where Christ demonstrated servant leadership was the washing of His disciples' feet, although He was a leader (John 13: 3-5). He performed a servant's duty to them, so that they could learn from Him to be leaders that serve (John 13: 13-15). Jesus' life up to His death showed the attributes of servant leadership such as the sacrificing spirit, leading by example and helping the followers grow.

\section{In the Business Sector}

The case of Southwest airlines also shows the benefits of servant leadership. The company managed to increase its sales by caring for their customers. One example often cited is when a mother of a crying toddler requested the airline's air hostess to rush out of the plane to look for some food to sooth the crying baby when the plane had brief stop. The hostess did not just offer to buy the food for the crying baby alone; she bought for the rest of the babies that were in that flight. This impressed the mother of the crying baby and the other passengers. This gesture showed a selfless regard for others, a spirit that helped in earning a good reputation for the airline. Servant leaders therefore serve the interests of their stakeholders, customers included.

\section{Implications in Business Management}

Servant leadership has implications in that the servant leader models the way business should be administered for the subordinates to follow suit. This would then give direction to the attainment of the desired institution results or outcomes. Through this modelling, employees are groomed to be servant leaders as they are involved in decision-making of the institutions. This involvement compels employees to have ownership of the organisation and motivates them to put their all in execution of their duties without anyone coercing and pushing them to perform. This employee organizational ownership is likely to result in increased productivity of quality.

\section{Conclusions and Recommendations}


This section gives conclusions and recommendations based on the discussion of various concepts of Servant Leadership.

\section{Conclusion}

Servant leaders serve the interests of others and of the community first before their own interests. A servant leader is a good steward. As much as there are misconceptions of how a leader can be a servant, servant leadership does not make the leader a servant but a leader that serves others as Jesus Christ served humanity. Servant leadership therefore entails that a leader in a business entity models, empowers, grooms and motivates employees to have ownership of the business without any coercion. Although servant leadership is difficult to test empirically, its existence cannot be in doubt since it has been practiced since Bible times. Although there is no common definition for servant leadership, many authors agree on most of its attributes, antecedents and outcomes. As presented in this paper. Therefore, leaders should abide with concepts given in this paper for them to become servant leaders.

\section{Recommendation}

In a world that is full of cheating and selfishness, fraud and scandals, servant leadership should be an ideal leadership in the present time. The outcomes of servant leadership are attractive for many businesses as they include optimized organisational performance which is critical for the survival of an organisation. The concept is also in line with the modern leadership styles such as transformational leadership, team leadership and visionary leadership. More studies should therefore be done on the application of servant leadership in business management. Unlike other management theories that are centred on activities that demand ownership, management and control to attain the set objectives, servant leadership derives authority from one's influence on the subordinates not from one's position.

\section{Reference}

Barter, A. (2019). Patience and Discernement : Key to servant leadership.

Cable, D. (2018). How humble leadership really works, Business Review, April 23, 2018.

Chawla, N. (2002). Mother Teresa, the Centenary Edition. New Delhi: Penguin Books India

Culpan, R., \& Trussel, J. (2005). Applying the agency and stakeholder theories to the
Enron debacle: An ethical perspective. Business and Society Review, 110(1), 59-76.

Dod, R., Achen, R. M., \& Lumpkin, A. (2018). Servant Leadership and Its Impact on Ethical Climate. The Journal of Value Based Leadership 11(1), 1-22.

George, C. F., \& Robert, E. L. (1992). Leading and managing your church. Grand Rapids, MI: Fleming H Revell.

Greenleaf, R. K. (1977). Servant leadership: A journey into the nature of legitimate power and greatness. Mahwah, NJ: Paulist Press

Hunter, J. C. (2004). The world's most powerful leadership principle: How to become a servant leader. New York, NY: Crown Business.

Hunter, K. R. (1989). Moving the church into action. St. Louis, MO: Concordia Publishing House.

Hutcheson, R. G. (1979). Wheel within the wheel: Confronting the management crisis of the pluralistic church. Atlanta, GA: John Knox Press.

Jit, R., Sharma, C. S., \& Kawatra, M. (2017). Healing a broken spirit: Role of servant leadership. Vikalpa, 42(2), 80-94.

Joyner, R. L., Rouse, W. A., \& Glatthorn, A. A. (2013). Writting the award winning thesis or dissertation: A step-by-step guide ( $3^{\text {rd }}$ ed.). Thousand Oaks, CA: Corwin

Laub, J. A. (1999). Assessing the servant organization; Development of the Organizational Leadership Assessment (OLA) model. Dissertation Abstracts International, 60(2), 1-115.

Lunenburg, F. C. (2011). Expectancy theory of motivation: Motivating by altering expectations. International Journal of Management, Business, and Administration, $15(1), 1-6$.

Malphurs, A. (1992). Developing a vision for ministry in the $21^{\text {st }}$ century. Grand Rapids, MI: Baker Books 
Northhouse, P. G. (2013). Leadership: Theory and practice (6th ed.). Thousand Oaks, CA: Sage Publication. '

Patterson, K.A. (2003). Servant leadership: A theoretical model. School of Leadership Studies, Regent University. From https://pdfs.semanticscholar.org/ed70/d23a1 ab032df4e13532d5a92d7f657eb.pdf?_ga=2.

$1367 \quad 30934.769444087 .1590157623-$ $1771361040 . \quad 1570450673$

Parks, S. D. (2005). Leadership can be taught. Boston: Harvard Business School Publishing.

Reinke, S. J. (2004). Service before self: Towards a theory of servant-leadership. Global Virtue Ethics Review, 5(3), 30-57.

Rivkin, W., Diestel, S., \& Schmidt, K. H. (2014). The positive relationship between servant leadership and employees' psychological health: A multi-method approach. German Journal of Research in Human Resource Management, 28(1-2), 52-72.

Rosenberg, S. (2005, February). The world's most powerful leadership principle: How to become a servant leader [Review of the book The World's Most Powerful Leadership Principle: How to Become a Servant Leader, by James C. Hunter]. The Academy of Management Executive, 19(1), 162-163.

Russell, R. F., \& Stone, A. G. (2002). A review of servant leadership attributes: Developing a practical model. Leadership \& Organization Development Journal

Sendjaya, S. \& Sarros, J. C. (2002). Servant leadership: Its origin, development and application in organisations. Journal of Leadership and Organisational Studies, 9(2), 57-64.
Shaw, C. R., \& McKay, H. D. (1942). Juvenile delinquency in urban areas. Chicago: University of Chicago Press.

Spears, L. C. (2010). Character and servant leadership: Ten characteristics of effective, caring leaders. The Journal of Virtues \& Leadership, 1(1), 25-30.

Stone, A. G., Russell, R. F, \& Patterson, K. (2004). Transformational versus servant leadership: A difference in leader focus. Leadership \& Organization Development Journal, 25(4), 349-361

Udani, Z. A. S., \& Lorenzo-Molo, C. F. (2012). When servant becomes leader: The Corazon C. Aquino success story as a beacon for business leaders. Journal of Business Ethics, 116, 373-391.

Van Dierendonck, D., \& Nuijten, I. (2011). The servant leadership survey: Development and validation of a multidimensional measure. Journal of Business and Psychology, 26(3), 249-267.

Vondey, M. (2010). The Relationships among servant leadership, organizational citizenship behaviour, person-organization fit, and organizational identification. International Journal of Leadership Studies, 6(1),3-27.

Wilkes, G. N. (1998). Jesus on leadership. Illinois: Tyndale House Publishers, Inc.

Wis, R. M. (2002). The conductor as servant-leader. Music Educators Journal, 89(2), 17-23.

Wren, D. A. \& Bedeian, A. G. (2009). The evolution of management thought $\left(6^{\text {th }}\right.$ ed.). Hoboken, NJ: John Wiley \& Sons. 